\title{
Peningkatan Nilai Nutrisi Pakan Sapi Betina Induk Melalui Pemanfaatan Lamtoro di Kelompok Tani Ternak Pade Genem Kecamatan Sekarbela Kota Mataram
}

\author{
Syamsul H. Dilaga*, Dahlanuddin, Yusuf A. Sutaryono, Suhubdy, dan Hermansyah
}

Fakultas Peternakan Universitas Mataram,Mataram, Indoneisa

\section{Article history}

Received: 19 Februari 2019

Revised: 06 Maret 2019

Accepted: 10 Marer 2019

*Corresponding Author:

Syamsul H. Dilaga, Universitas Mataram, Mataram, Indonesia;

Email: shdilaga@gmail.com
Abstract: Improving nutritional value of feed using Leucaena leucocephala is attainable for everyone as it could easily grow in agriculture land and often found as tree fences in farmers' residential area. Leucaena leaves contain high valuable nutrition, which favored by the cattle and likewise the increase live weight cattle thoroughly. A community-service based program was carried out at farmer group of Pade Genem in Sekarbela district, Mataram. This program aimed to provide training for cattle farmers on how to feed cattle using leucaena, introducing the methods of reducing anti-nutritional factors that naturally producing by leucaena, as well as planting strategy for feeding and environmental greening. Participative approach was used in the education and training activities through counseling, discourse and illustration methods. Success of program is indicated by enthusiasm and involvement of participants, as well as implementation and adoption.

Keywords: nutrition, cow, leucaena leucocephala

Abtrak: Peningkatan nilai nutrisi pakan menggunakan daun lamtoro dapat dilakukan oleh semua orang karena daun lamtoro merupakan jenis legum pohon yang banyak dijumpai di sekitar lahan pertanian maupun digunakan sebagai pagar hidup di areal pemukiman petani. Daun lamtoro mempunyai nilai nutrisi tinggi, sangat digemari oleh sapi. Bobot badan sapi bertumbuh dengan baik dan menguntungkan bagi mereka yang menggunakan lamtoro sebagai pakan sapinya. Kegiatan Pengabdian dilaksanakan di Kelompok Tani Ternak Pade Genem Kecamatan Sekarbela kota Mataram. Tujuan dilaksanakannya kegiatan ini untuk memberikan pelatihan tentang tanaman lamtoro sebagai pakan ternak bagi sapi betina induk, peragaan cara-cara mengurangi zat anti nutrisi yang terdapat dalam daun lamtoro, cara pembibitan dan penanaman benih lamtoro untuk pakan dan penghijauan. Metode yang digunakan dengan metode partisipatif dalam bentuk pendidikan dan keterampilan, berupa penyuluhan, ceramah, dan peragaan. Keberhasilan kegitan ditandai dengan antusiame dari peserta dalam kegiatan, keaktifan dalam dskusi, dan menindak lanjuti dengan menanam lamtoro di lahan mereka sendiri. Sehingga nantinya akan digunakan sebgai pakan ternak mereka

Kata kunci: nutrisi, sapi betina induk, lamtoro 


\section{PENDAHULUAN}

Rumput lapangan dan aneka hijauan lainnya yang diambil di sawah maupun pinggir jalan, serta limbah pertanian adalah pakan yang biasa diberikan kepada sapi betina induk oleh petani di Kelompok Tani Ternak Pade Genem Kecamatan Sekarbela Kota Mataram. Pakan tersebut memiliki nilai nutrisi yang rendah, sehingga berpengaruh terhadap produktivitas sapi yang dipelihara.

Sekitar $65-75 \%$ biaya pemeliharaan ternak betina adalah untuk pemeliharaan fertilitas dan bobot sapih pedet. Kedua faktor itu sangat mempengaruhi keberhasilan bisnis perbibitan. Karena kalau pakan tidak sesuai dengan kebutuhan ternak, dapat dipastikan kegagalan akan terjadi pada aspek reproduksi ternak betina. Kegagalan bunting, menyebabkan kehilangan waktu, tenaga, dan biaya bagi usaha perbibitan. Besarnya kerugian reproduksi ditaksir menyumbang $88 \%$ calf crop (panen pedet hidup atau mati). Kegaagalan kedua adalah berupa kehilangan pedet disebabkan kematian pedet sejak lahir sampai disapih. Besar kerugiannya diduga sekitar $6 \%$.

Partama (2013) menyatakan bahwa, pemberian pakan pada sapi bunting hendaknya memperhatikan hal-hal berikut: a). sapi diberi rumput dan legume secara ad libitum, dengan perbandingan 60:40, b) berikan pakan tambahan yang mempunyai kandungan protein kasar (PK) sekitar 14-16\% sebanyak 0,5-1,0 kg/ekor/hari, c) air minum disediakan ad libitum, dan d) berikan tambahan mineral $\mathrm{Ca}, \mathrm{P}, \mathrm{Zn}$, dan garam.

Para produsen sapi bibit biasanya tidak melakukan pemberian suplemen protein tatkala rumput maupun leguminosa diberikan dalam keadaan kering. Hal ini biasa dilakukan pada musim kemarau. Sapi yang dikandangkan, umumnya diberi ransum berupa konsentrat dalam jumlah banyak. Biasanya diberikan pula tambahan suplemen protein sekitar $0,5 \mathrm{~kg}$ sampai $1,0 \mathrm{~kg}$ per ekor setiap hari (Ensminger. 1978). Dijelaskan pula lebih lanjut bahwa selain enersi, protein, mineral, dan air, maka vitamin juga penting untuk diberikan kepada sapi induk.

Untuk memenuhi kebutuhan nutrisi sapi betina induk, perlu upaya peningkatan nilai nutrisi pakan menggunakan daun lamtoro. Daun lamtoro merupakan jenis legum pohon yang banyak dijumpai di sekitar lahan pertanian maupun digunakan sebagai pagar hidup di areal pemukiman petani. Hasil penelitian kalangan pakar seperti dikutip Dilaga, dkk. (2017) bahwa lamtoro mempunyai nilai nutrisi tinggi yaitu protein kasar 22,0-36,8\% dan energy bruto $20,1 \mathrm{KJ} / \mathrm{g}$. Dahlanuddin, dkk. (2006) melaporkan bahwa penggunaan lamtoro pada pakan pedet sapi bali dengan pakan basal rumput lapangan memberikan pertumbuhan yang lebih baik jika dibandingkan dengan hanya diberikan rumput lapangan saja. Hal ini tentu akan berdampak kepada efisiensi usaha mereka. Apalagi harga konsentrat yang merupakan sumber energy dan protein dipandang masih cukup mahal oleh peternak, sehingga salah satu alternatif penanggulangan kekurangan protein pada pakan sapi adalah dengan pemberian daun lamtoro.

Adapun tujuan dilakukannya pengabdian kepada masyarakat ini adalah memberikan pengetahuan dan keterampilan kepada peternak tentang manfaat daun lamtoro yang memiliki nilai nutrisi tinggi yang dapat mengurangi ketergantungan peternak pada konsentrat komersial, cara menyemaikan dan menanam lamtoro untuk pakan dan penghijauan serta efisiensi pemanfaatan lamtoro sebagai pakan ditinjau dari segi ekonomi. 


\section{METODE}

Kegiatan pengabdian pada masyarakat ini dilaksanakan dengann metode partisipatif dengan pendekatan dalam bentuk pendidikan dan keterampilan, dengan kegiatan penyampaian materi pendidikan berupa penyuluhan dan ceramah, peragaan cara-cara mengurangi zat anti nutrisi yang terdapat dalam daun lamtoro, cara pembibitan dan penanaman benih lamtoro untuk pakan dan penghijauan.

Evaluasi dilakukan dalam dua tahap yaitu a) dilaksanakan selama kegiatan penyuluhan/ ceramah dan latihan keterampilan, dan b) setelah kegiatan penyuluhan/ceramah dan latihan keterampilan berlangsung. Bentuk/kriteria evaluasi dalam kegiatan ini dilakukan dengan cara melihat jumlah kehadiran peserta, tanya jawab/diskusi, serta keterampilan tentang cara mengurangi zat anti nutrisi yang terdapat dalam tanaman lamtoro, cara membibitkan dan menanam benih lamtoro untuk pakan dan penghijauan.

\section{HASIL DAN PEMBAHASAN}

\section{Kesungguhan dan keaktifan peserta mengikuti penjelasan materi penyuluhan}

Dalam pelaksanaan kegiatan pengabdian ini, kami didampingi oleh petugas dari Dinas Pertanian Kota Mataram dan Penyuluhnya yaitu Herawati S.Pt dan Desy Fridjayanti S.Pt.

Adapun materi pengabdian disampaikan oleh masing-masing anggota tim, kemudian setelah semua pemateri selesai menyampaikan paparannya, dilanjutkan dengan diskusi/Tanya jawab. Para peserta sangat antusias mengikuti penyuluhan serta mempunyai kemampuan memadai untuk memahami materi penyuluhan, terbukti dari pertanyaan yang mereka sampaikan (Gambar 1).

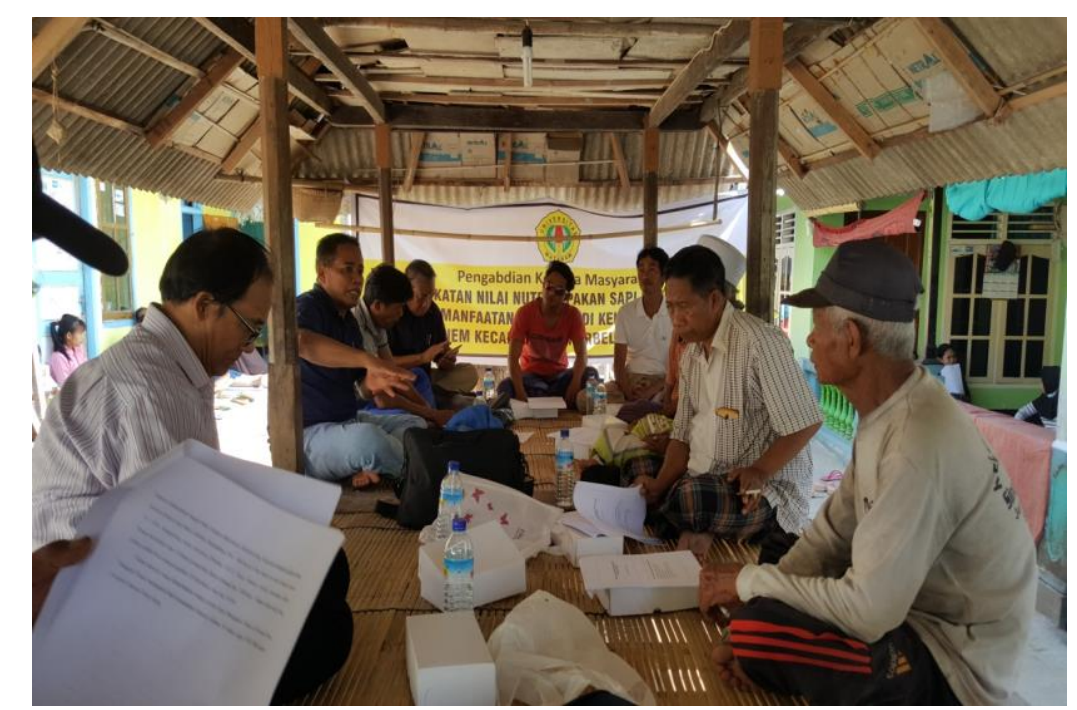

Gambar 1. Anggota Kelompok Tani Ternak Pade Genem mengikuti Penyuluhan 
Adapun beberapa pertanyaan yang mengemuka dalam diskusi adalah:

Penanya-1 Ramidah bertanya Semua anggota kelompok tani ternak Pade Genem tidak ada yang punya lahan. Mereka semua adalah petani gurem, petani penyakap. Lalu di mana kami bisa menanam benih lamtoro taramba yang bapak berikan kepada kami untuk sumber pakan bermutu bagi sapi kami pak? Jawabnya adalah bahwa lamtoro taramba ini tidak mesti ditanam di lahan sawah. Setelah ibu-bapak menyemaikan,-maka bibit lamtoro ini dapat ditanam di pekarangan rumah, atau ditanam untuk dijadikan pagar hidup, ditanam di kebun, atau di lahan tidur. Tanaman ini dapat di panen puluhan tahun lamanya, yakni dapat mencapai 30 tahun. Setelah tanaman mencapai umur 1 tahun, harap dipangkas agar tingginya sekitar 1,5 m dari permukaan tanah. Maksudnya adalah untuk memudahkan ibu-bapak memanen daunnya setiap diperlukan.

Penanya ke-2 adalah H. Baharuddin: bagaimana cara pemberian lamtoro kepada sapi dan apakah sapi yang diberi lamtoro tidak mencret?

Jawab: Pemberian pakan yang baru pertama kali kepada sapi mesti secara bertahap, sedikit demi sedikit. Bahkan kalau tidak mau dimakan sama sekali, maka sapi tersebut terlebih dahulu dilaparkan selama satu hari, kemudian berikanlah pakan daun lamtoro yang telah disiapkan. Kalau sudah terbiasa, maka jumlah pemberiannya dapat ditingkatkan. Pemberian lamtoro dapat dicampur dengan rumput atau pakan yang biasa ibu bapak berikan kepada sapi. Dengan cara seperti itu sapi tidak mencret.

Penanya ke-3 Rakmah: Kami punya sapi semua betina. Apakah daun lamtoro boleh diberikan kepada sapi bunting?

Jawab: Daun lamtoro boleh diberikan kepada sapi bunting. Pemberiannya tidak boleh $100 \%$. Kalau sapi jantan untuk penggemukan boleh diberikan 100\%. Sapi betina bunting baik diberikan $30 \%$ saja dari jumlah pakan yang diberikan. Misalnya ibu bapak memberikan rumput segar $50 \mathrm{~kg} / \mathrm{ekor} / \mathrm{hari}$, maka daun lamtoro segar dapat diberikan sekitar $15 \mathrm{~kg} /$ ekor/hari. Dengan demikian, bobot lahir pedet akan lebih tinggi, demikian pula dengan produksi air susu induk akan meningkat.

Penanya ke-4 Suhardi: Saya punya sapi jantan hasil IB umur 2,5 tahun ditawar Rp. 12 juta pada awal bulan ini, tapi saya belum mau menjualnya. Saya akan jual setelah harganya bisa mencapai Rp 15 juta. Kira-kira lagi 3 bulan dari sekarang ini. Bagaimana menurut bapak?

Jawab: Saran saya lebih baik bapak jual sekarang daripada menunggu harga sesuai keinginan bapak. Mengapa? Karena kita tidak tahu bagaimana nasib barang hidup yang bapak pelihara ini 3 bulan kedepan, apakah masih sehat, sakit, mati, atau hilang diambil orang. Bapak pelihara selama 3 bulan lamanya tentu sapi tersebut butuh asupan pakan, minum, dan aneka macam perawatan lainnya. Semua itu tentu butuh waktu, tenaga, dana, dan perhatian. Tetapi kalau bapak jual sekarang dan hasil penjualannya bapak belikan lagi sapi bakalan, lalu dipelihara seperti cara memelihara sapi yang telah dijual itu, tentu bapak memiliki peluang lebih banyak memelihara dan menjual sapi dalam satu masa tertentu, misalnya setahun. Tegasnya, laju putaran usaha bapak menjadi lebih banyak dalam jangka waktu satu tahun misalnya 2x, jika dibandingkan dengan cara yang bapak lakukan saat ini. 


\section{B. Pendampingan dan konsultasi usaha}

Penyemaian dan penanaman bibit lamtoro dapat dilakukan dengan beberapa cara, yakni:

\section{Menggunakan Cabutan (Stum)}

- Biji sebaiknya ditanam pada awal musim hujan atau ketika tanah masih basah/lembab

- Anakan dicabut secara hati-hati setelah tinggi tanaman mencapai $30 \mathrm{~cm}$

- Pencabutan dilakukan lurus sejajar batangnya dan diusahakan agar akarnya tidak putus

- Pengangkutan diatur sedemikian rupa, disusun searah, akar dengan akar dan daun dengan daun.

\section{Menggunakan Semaian dalam plastik polybag}

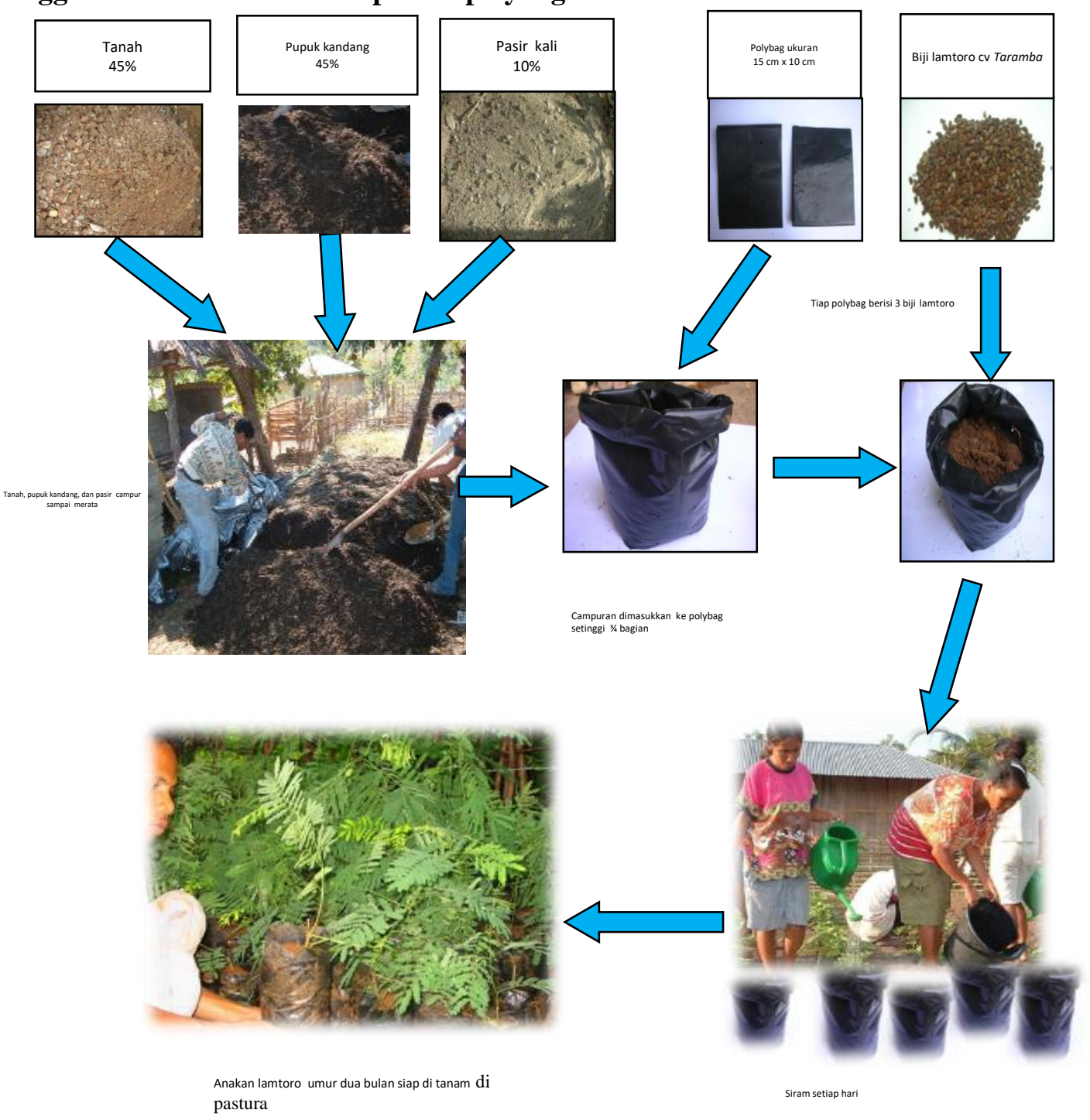

Gambar 2. Penyemaian lamtoro dalam plastik polybag (Dahlanuddin et al., 2014).

Penyemaian bibit lamtoro dilakukan dalam plastik polybag dengan cara meletakkan 1-3 biji lamtoro. Setelah benih berumur 2 bulan atau tinggi benih mencapai $30 \mathrm{~cm}$, maka benih siap untuk dipindahkan 
ketempat penanaman. Sebelum dipindahkan untuk ditanam di padang penggembalaan, terlebih dahulu disiapkan campuran media tumbuh yang terdiri atas tanah : pupuk kandang : pasir dengan perbandingan $45: 45: 10$.

Adapun cara melakukan penyemaian adalah siapkan polybag ukuran 15 x $10 \mathrm{~cm}$, lalu masukkan campuran media tumbuh kedalam polybag secukupnya, isi setiap polybag dengan 1-3 biji lamtoro, dan siram secara teratur

\section{Penyediaan pakan berkelanjutan untuk sapi betina}

Kriteria pakan berkualitas tinggi yang perlu dikembangkan adalah yang mengandung protein tinggi ( $\geq 20 \%$ ), mudah dicerna (kecernaan $\geq 60 \%$ ), produksi biomassa tinggi, disukai oleh ternak, mudah dikembangkan-dirawat-dipanen, tidak memerlukan input mahal seperti pupuk, tahan kering.

Mengapa perlu menanam pakan lamtoro di lahan sendiri? Agar pakan bermutu tinggi seperti lamtoro tersedia sepanjang tahun, meningkatkan laju pertambahan bobot badan sapi, memperpendek waktu yang diperlukan untuk mencapai berat potong, dapat diketahui berapa jumlah pakan (pohon atau luas lahan) yang harus disediakan agar kebutuhan sapi tersedia sepanjang tahun, agar pakan bermutu tinggi tersedia dekat dengan kandang sapi sehingga pemberian pakan menjadi lebih efisien (tenaga kerja, biaya), dan agar wanita dan anak-anak bisa membantu memberikan pakan pada sapi.

\section{Efisiensi pemanfaatan dan ekonomi lamtoro}

Keuntungan ekonomi penanaman dan penggunaan lamtoro yang ditanam di pekarangan rumah, lahan kebun baik untuk pakan maupun untuk penghijauan ada baiknya beberapa informasi yang serba sedikit berikut ini dijadikan sebagai bahan untuk mengenal manfaat ekonomi dari lamtoro sebagai pakan ternak.

Contoh diambil dari pengalaman peternak di Pulau Sumbawa yang telah mempraktikan penggunaan lamtoro sebagai pakan. Petani A memelihara sapi jantan berumur 18 bulan diberi lamtoro sebagai pakan tunggal selama empat bulan, dijual dengan harga Rp. 11 juta. Petani B punya sapi jantan, umur 60 bulan, dipelihara dengan cara dilepas merumput di pastura hanya dihargai Rp. 15 juta. Dari perbandingan harga dan waktu, ternyata petani A lebih efisien dan efektif memelihara sapi, karena dalam kurun waktu yang sama, petani A dapat memelihara sapi yang diberi pakan lamtoro sebanyak tiga kali periode dibanding kalau memelihara sapi di pastura.

Contoh lain, seorang peternak membeli empat ekor sapi bali pasca sapih seharga Rp.3 juta per ekor. Setelah dipelihara selama enam bulan dengan diberi pakan hanya daun lamtoro, kemudian dua ekor yang pertumbuhannya terendah dijual dengan harga $\mathrm{Rp} 13$ juta. Dua ekor sisanya yang pertumbuhannya tertingi dipelihara terus hingga mencapai 12 bulan. Kedua sapi ini kemudian dijual dengan harga Rp 30 juta. Pola seperti ini sudah tiga tahun lamanya dilakukan oleh peternak tersebut dan akan terus dilakukan seperti itu. Hal ini memberi petunjuk bahwa tanaman lamtoro mempunyai arti ekonomi tinggi bagi mereka sekaligus menegaskan bahwa lamtoro sangat bermanfaat bagi ternak.

Berdasarkan pada hasil Evaluasi yang dilakukan diperoleh hasil bahwa selama kegiatan penyuluhan/ ceramah dan latihan keterampilan dilaksanakan, para peserta cukup aktif melakukan diskusi. Mereka meminta perwakilannya untuk berbicara/berpendapat yang kemudian diamini oleh mereka. Kemudian setelah kegiatan penyuluhan/ceramah dan latihan keterampilan berlangsung, jumlah kehadiran peserta tetap dalam arti tidak ada yang meninggalkan tempat penyuluhan. Mereka sangat antusias menerima penyuluhan ini dan akan menerapkannya sebagai salah satu sumber pakan bermutu tinggi bagi sapi yang mereka pelihara. 
Seluruh peserta diajak untuk melihat dan mencoba memberikan daun lamtoro kepada sapi mereka di kandang kelompok. Ternyata sapi menyukainya. Selama ini mereka tidak pernah memberikan daun lamtoro kepada sapinya, karena khawatir sapi menderita mencret. Mereka akan menanam benih lamtoro setelah musim hujan tiba yaitu bulan November-Desember 2018, agar tidak merepotkan dalam penyiraman bibit. Para anggota KTT Pade Genem akan menanam bibit lamtoro kelak di halaman rumah maupun di areal kandangnya dengan cara dijadikan sebagai pagar hidup.

\section{KESIMPULAN}

- Pemberian daun lamtoro sebagai pakan sapi induk sudah mulai difahami oleh peternak. Mereka akan menyemaikan dan menanam bibit lamtoro di areal kandang dan rumah mereka begitu musim hujan tiba, yang diperkirakan akan datang pada akhir bulan November 2018.

- Penyuluhan/ceramah diikuti dengan tanya jawab dan latihan simulasi keterampilan dipandang efektif mempercepat pemahaman peternak akan pentingnya meningkatkan nilai gizi pakan sapi betina yang mereka pelihara.

- Pendampingan secara berkelanjutan terhadap peternak dalam mengelola usaha peternakan sapi betina induk perlu didampingi terus, terutama dalam pemberian pakan lamtoro, agar sapi yang mereka miliki dapat bertumbuh dan berkembang sesuai harapan.

\section{Ucapan Terima Kasih}

Terima kasih penulis sampaikan kepada Lembaga Penelitian Unram yang telah mendanai kegiatan pengabdian kepada masyarakat melalui dana DIPA BLU (PNBP) Pascasarjana Universitas Mataram Tahun Anggaran 2018.

\section{DAFTAR PUSTAKA}

Dahlanuddin, Oscar Y., Dennis P. 2006. Evaluation of Locally Available Goat Feeds Based on Potential Intake of Nutrients, Produets of Rumen Fermentation, Mierobial Protein Supply and Degradability of Protein. Laporan Penelitian ACIAR.

, Imran, Y.A. Sutayono, Suhubdy, SH. Dilaga, I Abdullah, dan W. Yasa 2014. Laporan

Survey, Identification and Design (SID) Padang Penggembalaan Doro Ncanga Kabupaten

Dompu Nusa Tenggara Barat. Kerjasama Dinas Peternakan dan Kesehatan Hewan Provinsi Nusa Tenggara Barat dengan Fakultas Peternakan Universitas Mataram

Dilaga, S.H., Imran, Santi Nururly, dan Padusung. 2017. Lamtoro Sumber Pakan potensial. Penerbit Pustaka Reka Cipta Bandung.

Ensminger M.E., dan C.G. Olentine, Jr. 1978. Feed and Nutrition Complete. The Ensminger Publishing Company. Clovis. California. USA.

Partama, IBG. 2013. Nutrisi dan Pakan Ternak Ruminansia. Penerbit Udayana University Press. 